\title{
Prospering Within Mathematics
}

\section{Della Dumbaugh}

\section{Introduction: The "Human Interest" of Mathematics}

In January 1919, the President of the Carnegie Institution, the mathematician R. S. Woodward, wrote to Leonard Dickson regarding the introduction to what would become Dickson's celebrated History of the Theory of Numbers. In particular, Woodward encouraged Dickson to "add the human interest which many of our friends who are professed humanists deny to our favorite science." From Woodward's perspective, this approach would give the book "the kind of sendoff its rich mine of contents so admirably deserves." ${ }^{1}$

Just think of it. Over a century ago, as members of the American mathematics community aimed to produce work and publications that would lend credibility to the discipline, Woodward encouraged a focus on the human aspect of mathematics as a prelude to Dickson's 1600-page study of number theory. Even more, Woodward viewed that approach as an admirable sendoff for the 400-year study. Woodward was ahead of his time. The young community aimed to create institutions to award doctoral degrees, build societies to bring colleagues together to discuss ideas, and establish publication venues to disperse research more broadly. In this broader context, however, Woodward urged Dickson, a leader in every aspect of this work at the time, to remember and celebrate the human being actually doing the work.

I accepted Woodward's call to focus on the humanity of mathematics in an invited plenary address I gave a century later (almost to the day) at the Joint Mathematics Meetings in January 2019 in Denver, Colorado, on "Prospering Through Mathematics." There, I explored the lives of Solomon Lefschetz, Emil Artin, Gertrude Cox, and Rudy Horne

Della Dumbaugh is a professor of mathematics at the University of Richmond. Her email address is ddumbaugh@richmond. edu.

${ }^{1}$ Robert S. Woodward to Leonard Dickson, January 14, 1919, Carnegie Institution Archives, Washington, DC, Dickson Papers.

Communicated by Notices Associate Editor Laura Turner.

For permission to reprint this article, please contact: reprint-permission aams.org.

DOI: https://dx.doi.org/10.1090/noti2380 with a focus on their human experience in the discipline. In particular, despite the challenges they each faced in their individual lives, they prospered through and within the contours of a career in mathematics. I intentionally chose the word "prosper" because it suggests abundance that propagates elsewhere. This paper grew out of that talk.

It is certainly true that this work could have featured many other members of the mathematics community. I focused on Lefschetz, Artin, Cox, and Horne, however, since they each arose in entirely different projects I pursued over the course of the last decade. In those seemingly disparate studies, I began to realize these colleagues shared a point of connection. They each achieved remarkable success in their mathematical careers and, yet, they each faced what could have been considered a deficit in a single moment-or collection of moments-where they felt "less than" others around them. They could have been defeated. Yet, they persisted. They found the courage to walk through those moments and complete the next task (and the one after that). In so doing, they advanced students and colleagues around them and helped shape a stronger American mathematical community. In particular, they show us that when colleagues visit the White House to accept the National Medal of Science or receive an endowed chair at Princeton or have a building named after them or work to help A-list movie stars see the beauty of mathematics, there are many other ordinary moments in their lives that came together to make that one possible. We have a tendency to focus on these more public moments when, in fact, the bulk of their careers and contributions occurred on ordinary days in ordinary offices with ordinary tasks. Just like us.

This look back at these members of the mathematical community can inform the way we move forward. We might, for example, identify with some aspect of the individual lives of Lefschetz, Artin, Cox, or Horne and use it as inspiration for our own. Taken together, their experiences call attention to the broad population that participates in the discipline of mathematics. Their lives underscore the critical importance of the current historical moment's emphasis on making space for others to belong. Using these 
insights as a foundation, readers can connect this past to the present and explore their own ways to prosper in the discipline and encourage others to prosper too.

\section{Solomon Lefschetz (1884-1972): Lost and Found}

In 1884, Solomon Lefschetz was born in Moscow to parents he would later describe as Russian Jews. His family moved to Paris a few weeks after his birth and he was subsequently educated in that vibrant city. Lefschetz spoke French at home and would learn Russian and many other languages throughout his life. Although his first love was mathematics, he studied engineering at the École Centrale Paris from 1902-1905 since he could not envision a career in mathematics in France without French citizenship. Once he earned his engineering degree, he immigrated to the US to gain practical experience. He was particularly interested in electrical engineering, "a non-existing speciality at the École Centrale" [Lefschetz2, p. i]. After a job at the Baldwin Locomotive Works near Philadelphia, he became an apprentice at Westinghouse Electrical and Manufacturing Company in Pittsburgh in January 1907. Just eleven months later, however, at the age of 23, he lost his hands and forearms in a transformer testing accident. After some months of convalescence, he returned to Westinghouse where he was assigned to an engineering department focused on the design of alternating current generators. He grew increasingly dissatisfied with the "extremely routine" nature of the work [Lefschetz2, p. ii]. He also struggled with the day-to-day and emotional aspects of adjusting to life as a young man with wooden hands covered with black gloves. Lefschetz's injury occurred before the long-term effects of trauma were understood fully. ${ }^{2}$ A colleague's wife described him as "a poor downcast creature, with only rudimentary artificial hands" [Hodge, p. 434].

This confluence of events inspired him to resume his studies of mathematics. In 1910 he enrolled as a graduate student in mathematics at Clark University where, under W. E. Story's guidance, he earned a PhD on the maximum number of cusps on a plane curve of specific degree. He earned his PhD in a year. While at Clark, he began his lifelong appreciation for-and use of - a strong mathematics library. But the Clark University library had a unique distinction he would not find elsewhere. It had exactly one other patron, a Miss Alice Berg Hayes, who "helped him to overcome his despair and face up to life" and would later become his wife and "a tower of strength to him for the rest of his life" [Hodge, p. 434].

After he completed his PhD, Lefschetz spent two years at the University of Nebraska and 12 years at the University of

\footnotetext{
${ }^{2}$ More than 100 years later, Bessel van der Kolk published his groundbreaking work on the long-term effects of trauma in his The Body Keeps the Score. In particular, van der Kolk identified the power of close human relationships for reclaiming lives. Although Lefschetz knew none of this at the time, he and his wife Alice figured it out together over the course of their lives.
}

Kansas. These 14 years in the west gave him the opportunity to work in "complete mathematical calm" [Lefschetz1, p. 854]. "Scientifically speaking," he would later describe them, "my 'years in the West' with total hermetic isolation played in my development the role of 'a job in a lighthouse' which Einstein would have every young scientist assume so that he may develop his own ideas in his own way" [Lefschetz2, p. iii]. He applied techniques from what was then known as analysis situs-topology today-to some of the main questions in algebraic geometry. His new approach revitalized algebraic geometry and bolstered the discipline that would become topology by showing its application to other fields in mathematics. As he famously described it, "it was my lot in life to plant the harpoon of algebraic topology into the body of the whale of algebraic geometry" [Lefschetz1, p. 854]. ${ }^{3}$ Lefschetz published this work in a series of papers including a Mémoire in French and its slightly modified and translated version in the Transactions of the AMS in 1921 [Lefschetz3]. The Académie des Sciences, Paris, awarded him the Prix Bordin in 1919 for the Mémoire and the AMS awarded him the Bôcher Memorial Prize for the translated version in 1924. This work became more widely available when he published it as a monograph in the Borel series and gained him recognition in the broader mathematical community.

In particular, in 1923, Henry B. Fine, Dean of the Faculty and Chair of the Department of Mathematics at Princeton, offered Lefschetz a visiting professorship in 1924-1925. That single year segued to a permanent position that extended throughout the rest of Lefschetz's career as he progressed through the ranks and, in 1932, became the second Henry B. Fine Research Professor when Oswald Veblen moved to the newly formed Institute for Advanced Study. Lefschetz held the Fine Chair-which was the most distinguished chair in American mathematics at the timeuntil age forced his retirement in 1953.

At the time of his initial move to Princeton, Lefschetz shifted his research interests from algebraic geometry to topology and, most notably, established the fixed-point theorem which bears his name. He delivered the 1930 AMS Colloquium Lectures on the topic of topology and published the associated volume, Topology, establishing the name topology in place of analysis situs [Lefschetz5; Griffiths, p. 275]. From 1925-1945, Lefschetz was considered the most outstanding American topologist and he helped build a strong research group at Princeton. ${ }^{4}$ Like many mathematicians, Lefschetz turned his attention to new areas of research during WWII. In particular, he began to oversee projects in differential equations supported by the

\footnotetext{
${ }^{3}$ Of course he did some teaching during this time too. He described his teaching in the west as an experience that "generally absorbs too much energy" [Lefschetz4, p. 345].

${ }^{4}$ [Steenrod] and [Nasar, p. 64].
} 
Office of Naval Research and the industry-funded Research Institute for Advanced Study. That Lefschetz began his work in DE when he was nearly 60 years old and devoted the next 25 years to it underscores his tremendous energy and his lifelong commitment to mathematics.

The move to Princeton brought more than new research interests for Lefschetz. His mathematical isolation came to an end as he surrounded himself with a wide circle of outstanding mathematicians including Oswald Veblen, Henry B. Fine, James Alexander, and Joseph Wedderburn, among others. He wasted no time embracing the department's commitment to growing a strong research program in the 1920s. In particular, he assumed the role as the department representative to the Graduate School Committee. He protected and advanced the interests of the graduate program to "build a research program through the cultivation of young mathematical talent" [Aspray, p. 361]. He did more than welcome students. He advised $29 \mathrm{PhD}$ students, many of whom went on to make significant contributions to the broader mathematical community.

The Canadian Albert Tucker, for example, earned his PhD under Lefschetz in 1932 and simplified many of his techniques. He worked alongside Lefschetz at Princeton, anchoring the department as chair for nearly two decades. Tucker would go on to oversee the thesis of Nobel Prize winner John Nash. John Tukey completed his 1939 dissertation on topology and later shifted his focus to statistics. He ultimately helped establish the Department of Statistics at Princeton and received the National Medal of Science in 1973 from President Richard Nixon. Lefschetz's 1940 PhD student Edward Begle also explored new research interests, directing the School Mathematics Study Group which, among other recommendations, proposed and developed what came to be known as "the new math." John McCarthy received his PhD in 1951 and later moved to Stanford where he became a computer scientist and founded the field of artificial intelligence. In 1971 he was awarded the Turing Award, often recognized as the highest distinction in computer science. This quick snapshot of Lefschetz's students points to his far-reaching influence in the broader mathematical community and beyond.

Lefschetz was also an effective administrator. He served as AMS president from 1935-1936 and chaired his department from 1945-1953. From 1945-1965 he held a visiting professorship in mathematics at the University of Mexico and helped establish a strong mathematics program there. In 1957, after the launch of Sputnik, Lefshetz helped rethink American engineering education. At the age of 80 , he still actively lectured in two languages at three institutions.

He also edited the Annals of Mathematics for thirty years, from 1928-1958. These were not just any thirty years to edit a mathematics journal in America. These were thirty years of tremendous growth for American universities and colleges and mathematics in particular. By the time he relinquished the editorship, the Annals was generally recognized as among the world's best mathematics journals [Steenrod]. Lefschetz accomplished this transformation by soliciting high-quality papers and establishing a reputation for rejecting second-class papers. He oversaw the publication of 1858 papers over his thirty year editorship. His assessment? It did not "overwhelm me with work" [Lefschetz4, p. 349].

He won many awards in his lifetime, including induction into the National Academy of Sciences and the US Presidential Medal of Science. He also won the highest awards offered by the countries of Italy and Mexico. The French government explored the idea of nominating him for the Nobel Prize. ${ }^{5}$ He lived a remarkable life. In 1970, at the age of 86 , with nearly the full arc of his life in view, Lefschetz offered his "Reminiscences of a mathematical immigrant in the United States" on the pages of the American Mathematical Monthly. There, he concluded by acknowledging a "budget of debts which I may never succeed in liquidating to the full" [Lefschetz4, p. 350]. In particular, he thanked his wife Alice "for her constant and unfailing encouragement" and he thanked the United States for its university structure which allowed him to follow his "deep bent" for mathematics.

It was a traumatic accident at the age of 23 that prompted Lefschetz to reorient his focus towards mathematics. That new professional path combined with his shared life with Alice changed him and, in turn, the course of our discipline.

One of Lefschetz's last responsibilities as AMS President was to write to the President of Notre Dame in early 1937 on behalf of a young European mathematician. As Lefschetz described the situation, "He is an Austrian Aryan, but his wife is one-half Jewish. They have a couple of small children and you know the rest...." (Lefschetz to O'Hara, January 12, 1937; see footnote 7). That mathematician? Emil Artin.

\section{Emil Artin (1898-1962): A New Homeland ${ }^{6}$}

Born in 1898 in fin de siècle Vienna to an art dealer father and opera singer mother, Emil Artin was influenced throughout his life by the rich cultural atmosphere of the late Hapsburg Empire. He was, as the algebraist Richard Brauer later described him, as much artist as mathematician. After his first semester at the University of Vienna in

\footnotetext{
${ }^{5}$ Lefschetz's Princeton colleagues convinced the French that his contributions in mathematics would not align with the prize guidelines. See M. Germot to J. Douglas Brown, January 6, 1960, Princeton University Archives, Princeton, New Jersey, Lefschetz papers.

${ }^{6}$ This section draws from D. D. Fenster, "Artin in America (1937-1958): A time of transition," In Emil Artin (1898-1962) Beiträge zu Leben, Werk und Persönlichkeit (K. Reich and A. Kreuzer, eds., with the collaboration of Catrin Pieri), Algorismus 61, Dr. Erwin Rauner Verlag, Augsburg, 2007; Della Dumbaugh and Joachim Schwermer, Emil Artin and Beyond: Class Field Theory and L-Functions, European Mathematical Publishing House, Zürich, 2015; and "Creating a life: Emil Artin in America," Bulletin of the American Mathematical Society 50 (2013), 321-330.
} 
1916, Artin was drafted into the Austrian Army, where he served until the end of World War I. In 1919 he enrolled at the University of Leipzig, and completed his doctorate in mathematics in only two years under the direction of Gustav Herglotz. His dissertation focused "On the Arithmetic of Quadratic Function Fields over Finite Fields." While at Leipzig, he also took courses in physics including mechanics, atomic theory, and quantum theory.

Artin spent the 1921-1922 academic year at the mathematically vibrant University of Göttingen studying mathematics and mathematical physics with Richard Courant and David Hilbert. He also attended the chamber music sessions hosted by Courant. He played all of the keyboard instruments and was an especially accomplished flautist. The following year he moved to the recently opened University of Hamburg. He achieved the rank of full professor in 1926. While at Hamburg, Artin oversaw the work of eleven doctoral students and published a veritable canon of mathematics that most mathematicians would only dream of publishing in a lifetime. He made a major contribution to field theory, the theory of braids, and, around 1928, he worked on rings with the minimum condition on right ideals, now called Artinian rings. In 1927, at the age of 29 , he solved the 17th of the 23 problems posed by David Hilbert in 1900. In the same year, he also proved a general law of reciprocity that included all previously known laws of reciprocity which had been discovered from the time that Gauss produced his first law.

In 1929 Artin married one of his students, Natalie Jasny. Natalie's Jewish background and Artin's personal sense of justice prompted them to leave Germany in 1937. This was no easy task. While the political situation necessitated Artin's departure from Germany, in terms of financial promise, he could hardly have arrived in America at a worse time. America was in the middle of a severe financial depression. Relative to mathematics, as early as 1932, a minimum of 200 members of the AMS were out of work. Some 240 institutions had dropped more than 2000 Americans from their faculties. With so many Americans out of work, Solomon Lefschetz and others who aided displaced German scholars had to work judiciously to contend with a nationalistic sentiment that raised concern over talented young American men so inadequately placed to accommodate displaced scholars. Even still, it was Lefschetz who appealed to Father John Francis O'Hara, then President of Notre Dame University, on Artin's behalf.7 At the time, Notre Dame had recently made a commitment to invest in staff and facilities to establish doctoral programs in a few disciplines, including mathematics. They had hired Karl Menger to lead this initiative. Lefschetz appealed to O'Hara

\footnotetext{
${ }^{7}$ Solomon Lefschetz to Father John O'Hara, January 12, 1937, Artin File (UDIS 101/43), University of Notre Dame Archives. For a full copy of this letter see "Creating a life: Emil Artin in America," p. 322.
}

suggesting the addition of Artin would give Notre Dame "two such stars in your firmament" that would allow the institution to "outclass in this branch of learning all but a small number of the oldest universities." And so it was done. The short-term position at Notre Dame provided a starting point, an opportunity for steady income in that critical first year in a foreign country. While there, he delivered a series of lectures on Galois Theory that became immortalized in the monograph by the same name and subsequently read by many aspiring mathematicians in his adopted country. ${ }^{8}$

Naturally, news of Artin's arrival at Notre Dame spread quickly among mathematicians. In particular, the chair of the math department at Indiana University in Bloomington (some 174 miles south of Notre Dame) recognized the value Artin could bring to their program. In his letter to his Dean, the chair described Artin as "almost on our doorstep" and as "the leading man in algebra in the world and one of the outstanding mathematicians of all fields." ${ }^{\prime 9}$ This close proximity and talent apparently convinced the Dean, and Artin was offered a permanent position the following year. Artin oversaw the work of two PhD students while at Indiana, including his only woman American PhD student, Margaret Matchett. At Indiana, Artin taught three classes plus the graduate seminar each semester. He taught across the mathematics curriculum, including, for example, trigonometry, advanced calculus, and differential equations.

The structure of this teaching load combined with the security of a permanent position allowed Artin to resume his mathematical research. After a very active decade from 1921-1931, the next 10 years of Artin's life were relatively quiet in terms of publications. In fact, from 1933-1940, Artin did not publish any mathematics at all. The topics he suggested to his graduate students and young collaborator, George Whaples, show that although he had taken something of a hiatus from publishing mathematics, he had remained keenly aware of developments in his fields of interest. ${ }^{10}$ The move to Indiana also allowed the Artin family to resume the active social life they had enjoyed in Hamburg, welcoming friends from many departments at the university. And music returned to the home.

He remained at Indiana until 1946 when he moved to Princeton. The Princeton opportunity seemed to revitalize Artin even more. His teaching style manifested itself in the form of 18 doctoral students, including John Tate and Serge Lang. He had indeed kept himself apprised of all the

\footnotetext{
${ }^{8}$ Emil Artin, Galois Theory, Notre Dame Mathematical Lectures, No. 2, University of Notre Dame Press, Notre Dame, 1942.

${ }^{9}$ K. P. Williams to Fernandus Payne, April 6, 1938, Indiana University Archives, Indiana University, Bloomington, Indiana, Artin File.

${ }^{10}$ For more on Artin's work with Whaples, see Della Dumbaugh and Joachim Schwermer, "The collaboration of Emil Artin and George Whaples: Artin's mathematical circle extends to America," Archive for History of Exact Sciences 66 (2012), 465-484.
} 
important developments in mathematics and involved himself in a research program of algebra, number theory, and topology. Artin advanced at Princeton holding positions as Professor of Mathematics, Dod Professor of Mathematics, and, finally, the Henry B. Fine Professorship. That Artin was awarded the Fine Chair following Oswald Veblen and Solomon Lefschetz, two cornerstones of the Princeton mathematics department and American mathematics as a whole, testifies to the success he achieved in America. Artin remained at Princeton until 1959 when he returned to Germany. He died in 1962 at the age of 64 of a heart attack.

When it became a political necessity for Artin and his family to leave their homeland, it was the mathematical community who worked to ensure a successful beginning for them in a new country. In this environment, Artin gradually regained his footing and went on to leave a strong imprint on American mathematics.

While Artin faced the reality of a declining political situation in Germany, Gertude Cox faced a different sort of challenge in the middle of America.

\section{Gertrude Cox (1900-1978):}

The Power of a Postscript

Gertrude Cox was born on a farm near Dayton, Iowa, in 1900. She spent her childhood "roaming in the woods by the river and wandering over the hills" [Anderson1, p. 117]. Her family moved to the rural town of Perry, Iowa, where she attended public school. She had a close relationship with her mother Emma and it was from her that she learned the "value and joy of doing for other people" [Anderson1, p. 118]. Early on, she aspired to help others. After graduating from high school, she taught in a one-room schoolhouse in Iowa and studied at the Iowa National Bible Training School before she spent the next two years acquiring a real education when she served as a housemother for 16 orphan boys in Montana. To prepare for the role of superintendent of the orphanage, she enrolled at Iowa State College for training and appropriate credentials. She majored in math because she found it easy. To prepare for her chosen career, she also took courses in psychology, sociology, and crafts [Anderson1, p. 118; Lohr, p. 318]. She earned her degree in 1929. To help pay expenses as an undergraduate, she did computing work for her calculus professor, George Snedecor. He had asked her to work with the comptometers in his computing lab. Many years later, Cox speculated that, as the only woman in his class, he may have hoped she would have more patience for this type of detail work than the men [Anderson1, p. 118]. Women in general were also hired for this kind of work since they could also be paid much less. ${ }^{11}$

\footnotetext{
${ }^{11}$ See David Alan Grier, When Computers Were Human, Princeton University Press, Princeton, 2005, and Margot Shetterly, Hidden Figures: The American Dream and the Untold Story of the Black Women
}

She continued at Iowa State and earned the first Master's in Statistics in 1931. At that time, the math department would not award an assistantship to a woman so Cox funded her graduate work with assistantships in psychology and art. After receiving her Master's degree, she wanted to teach high school but could not find a position since she did not have the requisite courses in education. Her love of people and her desire to learn "what made them tick" inspired her to pursue a PhD in child psychology at the University of California at Berkeley [Anderson1, p. 119]. Two years later, however, in 1933, Snedecor wrote to her, "I... am rapidly being drawn into statistical responsibilities for a large part of the College. Would you like to be a part of this? I think the opportunity is great" [Lohr, p. 318]. With this invitation, Cox set aside her studies at Berkeley and returned to Iowa to assist Snedecor with the newly organized Statistical Laboratory.

Initially, she joined two other faculty members at the Iowa State Statistical Laboratory. She oversaw the (human) computers performing data analyses and visited laboratories and fields to study the data collection process. This latter work aligned with her goal to use her math knowledge to help people and fostered collaborations with researchers to develop successful experimental designs and analyses. She took these insights into the classroom and attracted students from a broad range of disciplines to her "renowned" class on "Design of Experiments" [Anderson1, p. 119]. Working with Snedecor and others, including W. G. Cochran, Cox soon established herself as an expert in this field. Later, she and Cochran expanded and polished a collection of mimeographed notes which they published in 1950 as their classic Experimental Designs. ${ }^{12}$ Nearly three decades later, the statistician Frank Yates described this work as "the best practical book on the design and analysis of replicated experiments."13

Cox and Cochran outlined three basic principles for designing an experiment [Lohr, p. 319]:

1. Involve statisticians from the beginning. Set experiment objectives and analysis clearly at the outset.

2. "Randomize everything that can be randomized." This was a novel idea at the time.

3. Use "blocking" when possible. Blocks are homogenous groups of experimental units such as schools in the same city, identical twins, patients with the same demographics and disease stage, etc.

Mathematicians who Helped Win the Space Race, William Morrow, New York, 2016.

${ }^{12}$ William G. Cochran and Gertrude M. Cox, Experimental Designs, John Wiley \& Sons, Inc., New York, 1950.

${ }^{13}$ Frank Yates, "Gertrude Mary Cox, 1900-1978," Journal of the Royal Statistical Society 142 (1979), 516-517, on p. 516. 
As educator and administrator, Cox emphasized the collaborative nature of statistics and the critical importance of sound statistical practice.

But then a funny thing happened. In 1940, the School of Agriculture at North Carolina State College (later University) asked Snedecor to recommend candidates to head their new Department of Experimental Statistics. Snedecor showed Cox his list of five male candidates. Imagine how Cox must have felt. Snedecor had hand selected her from his Calculus class back in 1925, she had published her first paper under his direction in 1930, she had earned the first Master's degree in statistics from Iowa State in 1931, and he had personally invited her to return home from California to help him establish the Statistical Laboratory. In this latter role, she was out and about meeting with researchers to develop the best experimental designs and analyses, gaining a strong reputation for the Lab and herself along the way. Yet, when it came time to offer his recommendations for a new Department of Experimental Statistics at NC State College, he did not include Cox's name. How did she respond? She did not make a fuss. Instead, she simply asked, "why didn't you put my name on the list?" In response, Snedecor added a postscript to the accompanying letter that read "[i]f you would consider a woman for this position, I would recommend Gertrude Cox of my staff" [Anderson1, pp. 121-122]. That postscript changed the course of mathematics.

Although, "the south still retained something of the attitude that women are rather frail and could not be expected to do a man's job," as her colleague Cochran described it, the Search Committee "knew their business" and Cox was hired [Cochran, p. 97].

In building the department at NC State, Cox focused on two principles: staffing the department with faculty specializing in areas important to the institution (agronomy, animal nutrition, genetics, biology, etc.; Cox herself brought her own prowess in psychological applications) and, with the help of NC State President Frank Graham, extending the reach of the department to the entire university. For the former, she also aimed for her faculty to do "some missionary work on the importance of sound statistics" [Cochran, p. 97]. The latter ensured that her department would assume responsibility "for all teaching and consulting in statistics as well as receiving financial support from the other departments" [Cochran, p. 98].

This grand vision, grounded in practicality, characterized her style more broadly. Graham also encouraged and helped her secure a grant from the General Education Board of the Rockefeller Foundation to establish and lead an Institute of Statistics at NC State in 1944 and, two years later, expand it to the University of North Carolina at Chapel Hill with the founding of a Department of Mathematical Statistics there. Her administrative prowess allowed her to convince the celebrated statistician Harold Hotelling to leave Columbia to head the new department at Chapel
Hill. She led the Department of Experimental Statistics at NC State until 1949, when she moved to the Institute of Statistics full time. During and after the war, universities began to address research questions from government agencies and associated industries. To continue this association after the war, in the late 1950s Cox actively planned what became the Research Triangle Institute (RTI), located in close proximity to NC State, UNC, and Duke. She retired from her position at NC State and led the Statistics Division at RTI from 1960-1965.

Her superb administrative style hinged on hiring outstanding staff and then leaving them to do what they do best while she raised funding for them to continue their work. She inspired loyalty with this approach [Anderson2, p. 6]. She retired a second time and promoted statistics further afield in Thailand and Egypt, for example. ${ }^{14}$ All the while, she valued and spoke to PTAs and women's clubs. She traveled extensively, grew orchids, and generously hosted colleagues and friends [Anderson1, p. 128; Cochran, p. 98]. In all of these diverse settings, Cox remained "in command of just about every situation she encountered" [Anderson2, p. 6].

Cox's major contributions to mathematics and science came in the form of her ability to organize and administer programs. Cochran and other colleagues described her as a "builder" [Cochran, p. 98]. Her early accomplishments in psychological statistics and experimental design were also widely recognized. She became the first woman elected to the International Statistical Institute (1949), she served as president of the American Statistical Association (1956) and the International Biometric Society (1968), and she was founding editor of the journal Biometrics (1947-1955). Her influential co-authored book Experimental Designs remains in print today. NC State established a Graduate Fellowship and Distinguished Professorship in her honor. They also named a building after her. But the honor she cherished most was her election to the National Academy of Sciences in 1975 [Anderson1, p. 128].

In 1995, the celebrated historian Margaret Rossiter would publish the second of her groundbreaking works on the history of women in science, including mathematics, and note how rare it was for a woman to earn an appointment as a department chair at a coeducational institution in the forties, fifties, or sixties. Of those that did, Cox would be the most successful, not only for her accomplishments but also for the credit she received for her work. As Rossiter noted, "she not only managed to ride the wave of Big Science in the 1950s and 1960s but to be enough ahead of

\footnotetext{
${ }^{14}$ Patti Hunter offers an extensive look at Cox's work in Egypt in her "Gertrude Cox in Egypt: A case study in science patronage and international statistics education during the Cold War," Science in Context 22 (2009), no. 1, 47-83. In particular, drawing from the comprehensive work of Margaret Rossiter, Hunter offers an analysis of Cox in the broader context of women in mathematics and science.
} 
it" to contribute to the field with her work on experimental design and shape the broader contours of the discipline as it emerged in the 20th century [Rossiter, pp. 203-204].

Recently, the 2017 National Academies of Science workshop on "Refining the Concept of Scientific Inference when working with Big Data," an entirely contemporary topic, reaffirmed the value of Cox's contributions with their emphasis on collaboration with statisticians from the start, carefully designed experiments, and appropriate statistical inference [Lohr]. This ongoing presence of Cox's ideas testifies to the long-term influence of her foundational work.

As her beloved friend and NAS biographer Richard Anderson succinctly described her life, Cox "had that rare combination of administrative strength and love for her fellow man we so desperately need at the present time" [Anderson1, p. 117, my emphasis]. More than forty years have passed since Anderson noted the effectiveness of Cox's style for the "present time." Her combination of "administrative strength" and "love for her fellow man" is just as potent today.

\section{Rudy Horne (1968-2017): Unexpectedly Reaching the Masses ${ }^{15}$}

Rudy Horne shared a similar love for his fellow man, in particular for those from underrepresented groups with an interest in mathematics. Born in 1968, he grew up in the South Side of Chicago, not unlike another celebrated American by the name of Michelle Obama. In her memoir Becoming, Obama remembers that her mother, Marianne Robinson, observed that Michelle and her brother Craig were not the only two talented students in the South Side of Chicago, there were others too. As it turns out, Marianne Robinson was right. Rudy Horne was one of those talented students. He graduated in 1986, a year behind Obama, attending Crete-Monee High School in his neighborhood, just 37 miles from the Whitney M. Young Magnet school Obama attended. It was in high school that Horne discovered he liked calculus. He set off for the University of Oklahoma to pursue a college degree.

He majored in math and physics at Oklahoma. In the summer of 1989, he participated in the inaugural year of the SMART program at the University of Colorado Boulder. This 10-week undergraduate research program was designed for students from underserved populations interested in pursuing graduate degrees in STEM fields. The summer SMART program had lasting implications for Horne. He would return to the University of Colorado Boulder for graduate school, earning a Master's in Physics in 1994 and a Master's in Applied Math in 1996. He would go on to become the first African American to earn a doctorate in Applied Math from Colorado in 2001 with a dissertation

\footnotetext{
${ }^{15}$ This section draws from Della Dumbaugh, "The hidden figure of Hidden Figures: Rudy Horne," Notices of the American Mathematical Society 66 (2019), no. 2, 202-210.
}

that explored the long-distance transmission of signals via fiber optics. His strong background in physics and classical mathematics made the topic a natural fit for him.

While a graduate student at Colorado, Horne continued to work with the SMART program, only this time as a graduate assistant. He also worked in a multicultural engineering summer bridge program based on the work of Uri Treisman. He helped scores of minority engineering students succeed in their gateway calculus and physics courses. Horne's work with the Colorado SMART and Bridge programs served as a beginning for what would become a lifelong commitment to advancing underrepresented students in mathematics. His decade at Colorado gave him the opportunity to do mathematics and make a difference in people's lives, and earn a degree that would provide him with the credential he needed to continue this meaningful work throughout his career.

After a year in the California State University system, Horne joined the research team of Chris Jones, the Bill Guthridge Distinguished Professor at the University of North Carolina. From 2002-2005, Jones' research focused on non-linear optics and Horne's expertise in four-wave mixing brought a new approach to the team. His enthusiasm also buoyed the team. Jones celebrated Horne in a moving tribute in the form of a letter after Horne's death in 2017. Jones emphasized that Horne found success by doing and sharing mathematics. He also admired Horne for the way he bounced back from doubt, a lack of support, and rejection. Jones would go on to deliver the inaugural Rudy Lee Horne Applied Mathematics Lecture at the annual Council for African American Researchers in the Mathematical Sciences (CAARMS) in 2018.

Following this postdoc at UNC and a short time as a faculty member at Florida State University, Horne accepted a position at Morehouse College, a Historically Black College and University, in 2010. At Morehouse, Horne served as a tremendous role model for students interested in STEM, particularly mathematics. To his students, his enthusiasm for the subject made it seem like he was never working. But Horne did not disguise the difficulties his students would face once they left Morehouse. Instead, he promoted a spirit of "you can, you will, you should" in them. Morehouse provided the perfect home for Horne to continue to make a difference in the lives of the next generation of mathematicians. It also provided the unexpected opportunity for Horne to work with a Hollywood movie.

When Donna Gigliotti partnered with Theodore Melfi to shape Margot Shetterly's Hidden Figures: The American Dream and the Untold Story of the Black Women Mathematicians who Helped Win the Space Race into a movie, they were determined to capture the realities of a segregated workplace and the realistic home lives of middle-class African Americans in the 1960s. They were also committed to the accuracy of on-screen calculations. For this part of their work, they turned to the affable Rudy Horne to tutor 
the cast and crew on set. Fearing it would take too much time from his teaching and research, Horne initially turned down the offer to work as the mathematical consultant on the film. His colleagues, however, encouraged him to accept the position. Horne ultimately changed his mind and accepted the offer. He never regretted his decision.

Horne worked with the crew about a dozen times during the 43 days of filming in Atlanta. In her role as Katherine G. Johnson in the movie, Taraji P. Henson had to write and speak about mathematics. Horne was responsible for coaching Henson through this aspect of her work. When working with Henson, Horne encouraged her to think of the mathematics she had to write and speak as lines in a script. Henson broke out in hives as she anticipated these scenes. She wanted "to do right by Ms. Katherine Johnson... and her family, and I want to do right by her legacy."16 Gigliotti later suggested that Henson deserved an academy award for her mastery of mathematics for the film.

Horne also ensured that any mathematics that appeared on paper or on blackboards in the film aligned with historical conventions at NASA at the time. Sometimes these background scenes included Horne's own handwriting, such as the factoring of the quadratic by the young Katherine Johnson early in the movie.

Horne influenced the script by offering Euler's method as a way to solve a problem related to the calculation of the trajectory to bring John Glenn back to earth. Melfi really liked the idea. Later, Horne's students would recognize his presence in this scene. Horne "loved Euler's method" his former student Zerotti Woods recalled, "he droned on and on about [it] in numerical analysis." ${ }^{17}$ Horne's colleague and friend, Professor William Massey at Princeton, has noted lightheartedly that the mathematics community owes Horne a great deal for his efforts to ensure Henson pronounced Euler as "Oiler" rather than "Youler."

All of this was not lost on Henson. At the SAG awards in January 2017, it seems Horne and the spirit of the movie were everywhere present when she walked the red carpet. There, in that space that does not often feature mathematics, Henson encouraged, "I don't want another young girl thinking that math and science is not for her."18

Horne delivered the Blackwell-Wilkins Keynote Address at the 23rd annual CAARMS in July 2017. He spoke on "Hidden Figures: Bringing math, physics, history and race to Hollywood." Massey noted that Horne "lived long enough to see, to feel something was coming back to him, that more people became aware of what he did. Any researcher would

\footnotetext{
${ }^{16}$ Sarah Lewin, "On 'Hidden Figures' Set, NASA's Early Years Take Center Stage," Space.com, September 2, 2016, https://www. space.com/33886 -hidden-figures-movie-set-visit.htm7

${ }^{17}$ Zerotti Woods, phone interview, June 28, 2018.

${ }^{18}$ Sarah Lewin, "On 'Hidden Figures' Set, NASA's Early Years Take Center Stage."
}

give anything to have $1 / 100$ of the number of people that saw the movie to know about their work."19

Throughout 2017, Horne delivered talks, gave radio interviews, and appeared on NPR to discuss his work on the movie. In the fall of 2017, he missed a few days of class for a health-related issue. He returned and told his students everything was okay. But it wasn't. Horne died at the age of 49 on December 11, 2017.

It's difficult to consider Horne as an individual mathematician since he lived so fully engaged in the broader community. Chris Jones captured this aspect of Horne's life in his epistolary tribute to him. "Keeping your love of life and your love of mathematics as stable rocks in this stormy sea wasn't a tactic to survive, it was just the way you were," Jones wrote. "This must have been what allowed you to still give so much to each of us, your community of friends and avid supporters." 20

\section{Conclusion: Prospering Daily}

If we examine the lives of these four members of our community by geography of birth (Moscow, Vienna, Dayton, and Chicago) or chronological time (1884, 1898, 1900, and 1968) or mathematical interest (Algebraic Geometry \& Topology, Algebra \& Number Theory, Statistics, and Applied Mathematics), they offer a diverse look at our community. If we view them collectively, however, by the spirit of their lives, they share a singular bond: they prospered within the discipline of mathematics. Mathematics formed a foundation and offered a vision for their lives and they, in turn, used that platform to advance the subject and the people who pursued it. Their lives challenge us to fully invest the seemingly ordinary moments of our day.

This paper began more than a century ago with Robert S. Woodward urging Leonard Dickson to showcase the "human interest" of mathematics in the preface to his celebrated History of the Theory of Numbers. The rest of this paper reveals the rich possibilities of that "human interest." Taken together, the lives of Lefschetz, Artin, Cox, and Horne show us that mathematics as a discipline and the community that has grown around it combine to create the possibility for a prosperous life-even when faced with challenging circumstances. This blend of quiet focus on mathematics and participation in a larger group with shared interests fosters rich possibilities. It may not come easily or quickly, however. It may require you to intentionally look for opportunities or to recognize opportunities that come your way unexpectedly. It may require courage to advocate for others or for yourself. It may require you to hear a quieter voice. It may require unfathomable determination to overcome what initially seem like physical or

\footnotetext{
${ }^{19}$ William Massey, phone interview, July 27, 2018.

${ }^{20}$ Chris Jones, "In Memoriam: Rudy L. Horne," The Dynamical Systems Web, https://dsweb.siam.org/The-Magazine/Article/in-memoriam -rudy-7-horne.
} 
emotional setbacks. These mathematicians, however, show us how mathematics can form the foundation for a full and prosperous life. Chances are, you have already taken the first step by pursuing mathematics. The lives of Lefschetz, Artin, Cox, and Horne urge you to take the second.

\section{References}

[Anderson1] Richard L. Anderson, Gertrude Mary Cox, 19001978, National Academy of Sciences Biographical Memoirs 59 (1990), 117-132.

[Anderson2] R. L. Anderson, R. J. Monroe, and L. A. Nelson, Gertrude M. Cox-A modern pioneer in statistics, Biometrics 35 (1979), no. 1, 3-7.

[Aspray] William Aspray, The emergence of Princeton as a world center for mathematical research, 1896-1939, History and Philosophy of Modern Mathematics: Volume XI, edited by William Aspray and Philip Kitcher, University of Minnesota Press, 1988, pp. 346-366.

[Cochran] William Cochran, Gertrude Mary Cox, 1900-1978, International Statistical Review 47 (1979), no. 1, 97-98.

[Griffiths] Phillip Griffiths, Donald Spencer, and George Whitehead, Solomon Lefschetz: 1884-1972, National Academy of Sciences Biographical Memoirs 61 (1992), 269313.

[Hodge] William Hodge, Solomon Lefschetz. 1884-1972, Biographical Memoirs of Fellows of the Royal Society $\mathbf{1 9 . 0}$ (1973), 432-453.

[Lefschetz1] Solomon Lefschetz, A Page of Mathematical Autobiography, Bull. Amer. Math. Soc. 74 (1968), 854-879.
[Lefschetz2] Solomon Lefschetz, A Self-Portrait, Lefschetz Papers, Princeton University Archives, Princeton, New Jersey, 1954.

[Lefschetz3] Solomon Lefschetz, On certain numerical invariants of algebraic varieties with application to Abelian varieties, Trans. Amer. Math. Soc. 22 (1921), 327-482.

[Lefschetz4] Solomon Lefschetz, Reminiscences of a mathematical immigrant in the United States, Amer. Math. Monthly 77 (1970), 344-350.

[Lefschetz5] Solomon Lefschetz, Topology, Colloquium Publications, No. 12, American Mathematical Society, New York, 1930.

[Lohr] Sharon Lohr, Gertrude M. Cox and statistical design, Notices Amer. Math. Soc. 66 (2019), no. 3, 317-323.

[Nasar] Sylvia Nasar, A beautiful mind, Simon and Schuster, New York, 1998.

[Rossiter] Margaret W. Rossiter, Women scientists in America:

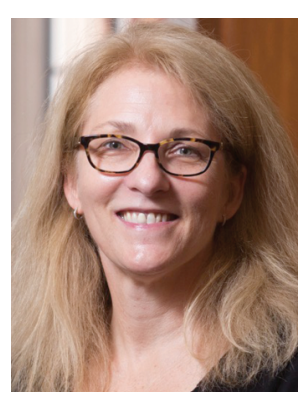

Della Dumbaugh Before Affirmative Action, 19401972, The Johns Hopkins University Press, Baltimore, 1995.

[Steenrod] Norman Steenrod to Professor John W. Green, June 27, 1962, Princeton University Archives, Princeton, New Jersey, Lefschetz Papers.

\section{Credits}

Author photo is used by permission of the University of Richmond.

\section{MEMBERS

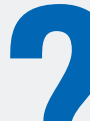

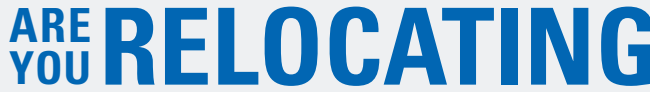

Please make sure that Notices and Bulletin find their new home.

Update your address at www.ams.org/member-directory.

You can also send address changes to amsmem@ams.org or:

Sales and Member Services

American Mathematical Society 201 Charles Street

Providence, RI 02904-2213 USA
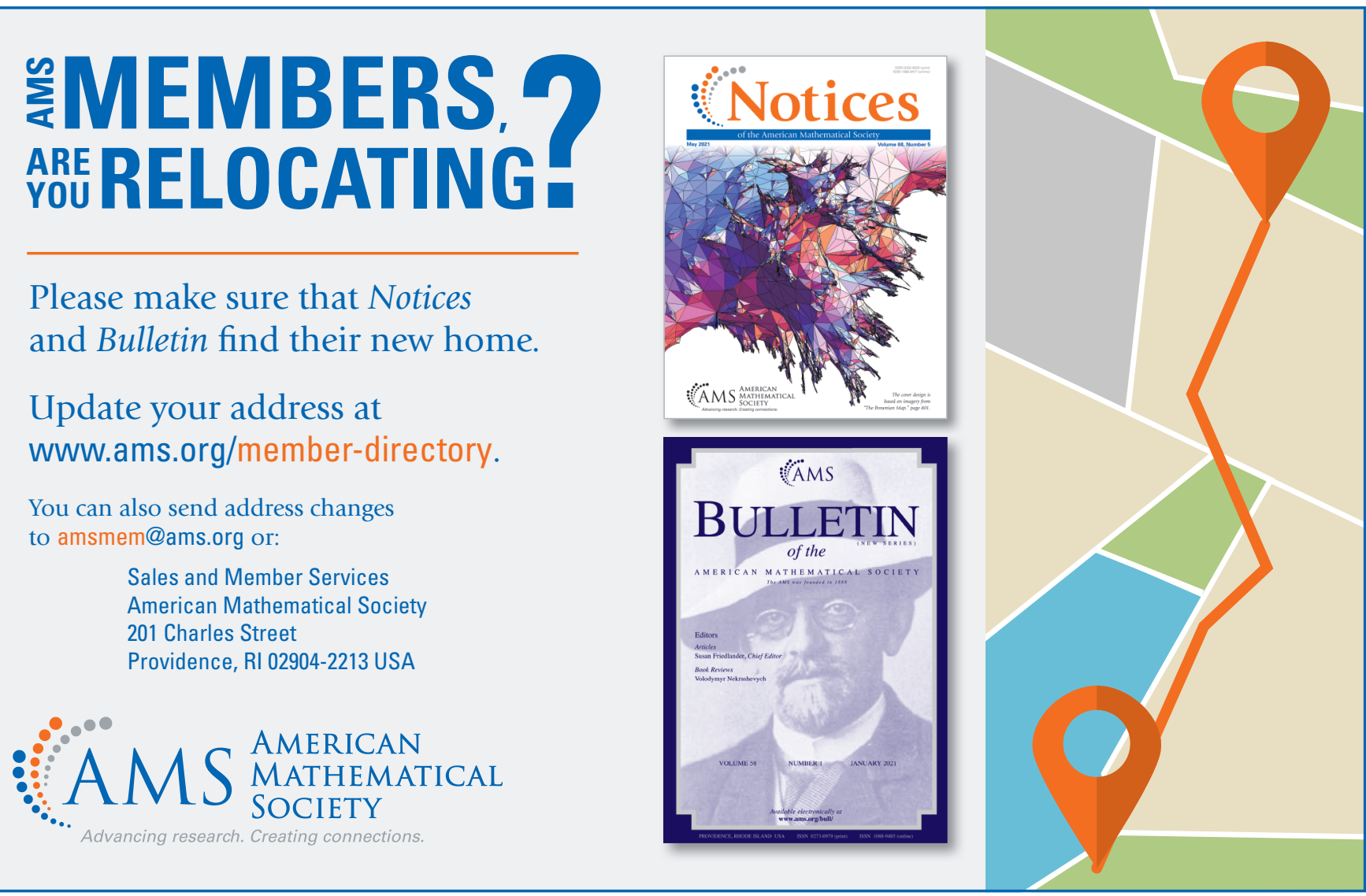